http://dx.doi.org/10.4314/jae.v18i1.11

\title{
Youth Migration and Agricultural Production: Analysis of Farming Communities of Osun State, Nigeria
}

\author{
${ }^{*}$ Ayinde, J. O., Torimiro, D. O. and Koledoye, G. F. \\ Department of Agricultural Extension and Rural Development, Obafemi Awolowo \\ University, lle Ife, Nigeria. \\ ${ }^{*}$ Corresponding Author: tundeyjoy@yahoo.com.
}

\begin{abstract}
$\overline{\text { Abtract }}$
The study investigated the causes and examined the effects of youth migration on agricultural production in Osun State, Nigeria. A two stage sampling produre was used to select 295 farmers in selected farming communities in the state. The mean age of the farmers was $49.67 \pm 9.70$ and 70.2 per cent were male while the mean years of formal education was $6.84 \pm 0.73$. Absence of social amenities, poverty and search for better education in the cities were the major causes of migration. Reduction in farm size, hired and family labour with negative consequence of food production were the predominant effects of youth migration on agricultural production. The findings also showed that agricultural production $(r=-0.634 ; p \leq 0.01)$ was negatively correlated with the effects of youth migration in Osun State. It is therefore, recommended that government and developmental stakeholders should ensure that social amenities are provided in farming communities of Nigeria in order to encourage youths retention in rural areas with the aim of enhancing rural and agricultural development in the State.
\end{abstract}

Key words: Youths, migration, farming.

\section{Intoduction}

Over 1 billion people around the world live in conditions of extreme poverty (UNDP, 2005). Approximately, about $75 \%$ of this population live in rural areas and are dependent on agricultural activities as their major source of livelihood (IFAD, 2007). Nigeria farming communities are highly marginalised with gross absence of basic infrastructures coupled with general neglect. This has led to negative development in many parts of the country. Before the discovery of crude oil in 1956 at Olobiri, Delta State, Nigeria, Nigerian economy was founded on agriculture as it provides food for ever increasing population, raw materials for the industries and also a source of employment for over $70 \%$ of the population (Olagunju, 2008).

The discovery of crude oil and its subsequent exploration brought a setback to Nigeria's economy in term of agricultural development. The government shifted attention from the agriculture sector to oil industry which encourages the drifting away of the abled-bodies youths from rural area to the urban centres leaving farming in the hands of the aged and the women as most of the wives were left behind in the villages. Subsequently, the 
number of farm land put into cultivation as a result of reduction in labour force diminished greatly, thus affecting production rate and income from agriculture.

Youth has been defined by many authors and organisations. The United Nations (2005) defines youth as all individuals aged between 15 and 24. In 2007, World Development Report, which focuses on 'the next generation', expands the definition of youth to include all young people aged between 12 and 24. The World Bank also in its definition of youth encompasses the 12 year-old pre-pubescent boy attending primary school in remote rural area and a 24-year old single mother of four children eking out an existence vending on the streets of a large rural village (Benell, 2007).

However, according to Torimiro (1999), youth can be described as a group of young people between the ages of 13 to 30 . They are known to be innocent but optimistic about life. Their nature is greatly affected by cultural and economic norms. Youth's life is full of energy, dreams and enthusiasm. Creative thoughts always keep imbibing in them. They can be instrumental in changing the whole rural scenario should their full potential be unleashed and effective participation be realized. This definition fits the situation in developing countries like Nigeria where over 30 years aged individual still lives under the roof of the parents. The Children and Youth-in-Agriculture Programme (CYIAPNetwork, 2006) took cognizance of the circumstances of poverty, unemployment and deprivations that are prevalent in Nigeria and some other developing countries which make some people to still depend on others for survival, protection and development up to the age of 40 years to define youth as people from ages 19 to 40 years.

Over the years, many studies have tried to identify the determinants of internal and international migration with special focus on male (Harris and Todaro, 1970; Falaris, 1979; Carvajal 1974; House and Rempel, 1980) but few studies seem to have been conducted in respect of youth migration and the effects on food production in the rural farming communities in recent times. Adams (1993) argued that migration is typically an individual decision made on the basis of the income that one expects to receive given his/her own specific human capital characteristics, such as age, education and skills. But recent studies emphasized that migration decisions are not taken by an individual in isolation but are influenced by the actual or intentional migration choices in one's peer group by the group's specific characteristics. Epstein (2002) opined that migrant networks, peer influences, immigrant clusters, herd behaviour, chain migration were the major causes of migration of people from one location to the other while Bauer et al., 2006; Epstein and Gang, 2004; Munshi, 2003 stated that social influences have a significant impact on the migrant's decisions about when and where to migrate.

The movement from rural to urban areas may create a negative impact on the quality of rural life especially when such migrants carry away their needed consumption into the city. Migration of young adults from the rural areas also placed a greater burden on the farmers. For farmers to cover the same area of land as when he had extra assistance, they must work much longer hours thus depriving themselves of some time for leisure or participation in various social activities (Adewale, 2005). Akangbe et al; (2005) in the study 'effects of youth miration on farmers' agricultural production in Egbedore Local Government Area of Osun State' stated that there was a significant difference on frequency of migration of both male and female as male migrates more than female. 
The study further found that the family labour which the rural farmers solely depend upon is reduced thereby leaving farming in the hands of the aged with consequences of low productivity, high cost of production, reduction in annual income and a drastic fall in standard of living. In the same vein, Anele (2003); Odigie and Orobosa (2008) reported that the concentration of the urban populations of many young persons, children alike, and women from farming (rural) communities engenders urban nuisance and growth of large urban agglomerates. The excessive migration from rural to urban areas is seen as the major cause of growth in most of these urban centres and its resulting increase in crime rate.

Theoretically, Heckscher-Ohlin model of migration predicts that labour migrates from regions where its marginal product is low to regions where the marginal product is high. In the absence of restrictions, labour migration should tend to bring about wage convergence between the host and source countries. The source country will experience a rise in wages and a fall in returns to capital, a rise in per capita income and a fall in national output. Applying this theory to the farming communities, people especially youths migrate from rural to urban, leaving farming in the hands of the aged. Based on the theory, these youths also have some obligations for where they migrated from. However, in farming communities, production tends to be low with negative consequence of food insecurity.

Nigeria is known for her success in agriculture and most of the foreign earnings as well as internal revenue usually come from the farming communities which are highly neglected in terms of infrastructures such as roads, schools, water, health facilities (Oyugi, 2000). This makes these farming communities to exhibit great poverty, poor health condition, ignorance, and other unfavouarble conditions due to lack of these amenties and a gross loss of able bodied youths who move out of these farming communities with the hope of getting better living conditions in urban cities (Torimiro, 2008). However, the menace of man power loss due to youth migration is worrisome. The growing rate of youth migration from the farming communities presents both problems and opportunities but with the problems overweighing the opportunities. Despite the fact that a lot of the migrants do not have success stories after migrating to urban centres, the situation has not improved. It is then seems indisputable that the common concern of migrant youths is to improve their economic prospects within the constraints of unemployment and lack of social and basic amenities in the farming communities in Nigeria. Against this background, the study investigated the consequences of youth migration on agricultural production in the farming areas of Osun State. Specifically, it investigated the causes of youth migration, examined the consequences on agricultural production and hypothesized that there was no significant relationship between the consequences of youth migration and level of agricultural production in the state.

\section{Methodology}

The study was conducted in Osun State, Nigeria. The State was carved out of Oyo State on August 27th, 1991 with its headquarters in Osogbo. The State lies in the southwest of the Niger valley in the sannavah and rainforest zones of the country. It lies between latitude $700^{\circ}$ and $900^{\circ} \mathrm{N}$ and Longitude $2.75^{\circ}$ and $6.75^{\circ} \mathrm{E}$. it covers a total area 
of approximately $37,680 \mathrm{~km}^{2}$. The State is bounded in the north by Kwara State, in the east by Ondo State and Ekiti State and West by Oyo State.

A two stage sampling procedure was adopted for sample selection. The first stage involved a purposive selection of four farming communities in each of the Agricultural Development Programme zones viz: Osogbo, Ife/ljesha and Iwo, based on the degree of farming activities. A total of 12 communities were used for the study. In the second stage, 26 practising farmers were selected with random sampling technique in each of the community and interviewed using interview schedule. A total of 312 respondents were sampled for the study. However, only 295 of the questionaires were completed and processed for analysis. Data were analysed using descriptive statistics such as frequency counts, percentages, mean, median while Pearson's Correlation analysis was used to test the hypothesis stated.

The dependent variable in the study was effect of youth migration which was measured as high, moderate or low using mean and standard deviation. The respondents were asked to indicate the effect of youth migration on the following: reduction in hired labour, reduction in family labour, reduction in household income, low rate of adoption of innovation, reduction in crop production, reduction in livestock production, reduction in community development activities and so on using a 5 point likert-scale of strongly agreed (5), agreed (4), undecided (3), disagree (2) and strongly disagreed (1) for positive statement and revised for negative statement. About 7 perceived effect of youth migration were identified. The minimum a respondent can score is 7 and maximum is 35. However, their level of effect of youth migration on agricultural production was categorised into three levels using their mean scores and standard deviation; based on the assumption that the level of effect scores assumed a normal distribution. This was operationalised as follows: High level was perceived by individual with mean level of effect score plus one standard deviation and above. Low level was perceived by individual with level of involvement score below mean level of effect score minus one standard deviation scores. Medium level of effect was perceived by individual with mean scores in between the high and low level of effect.

\section{Results and Discussion}

\section{Personal and socio-economic characteristics of respondents}

Table 1 shows the age distribution of the respondents. Majority (87.1\%) of the respondents were found within the age group of 31-60 years and few (7.2\%) were 61 years and above. The mean age of the farmers was $49.67 \pm 9.70$. This implies that majority of the respondents were active farmers. Majority $(70.2 \%)$ of the respondents were male while about (29.8\%) were female. This could be due to the fact that in most developing countries policy makers, technology developers and administrators typically assumed in the face of empirical data, that men were the farmers and women played only a "supportive role" as farmers' wives as reported by Ukpabi (2004), Torimiro et al. (2007). Therefore, this gender difference could be seen in the study area as shown in Table 1. Also, results in Table 1 indicate that majority (60.7\%) of the respondents were 
Christians while 39.3 percent were Muslims. This implies that the study area is Christians dominated.

Results on occupation revealed that majority $(59.0 \%)$ had their primary occupation as farming; about 26.1 percent indicated that their primary occupation was trading while only 14.2 percent indicated their primary occupation as artisan. In addition, only 0.7 percent of the respondents were civil servants. This implies that majority $(59.0 \%)$ were primary farmers. Also, results in Table 1 show that the mean farm size among the farmers was 2.74 acres with a standard deviation of 0.38 . Moreso, the mean household size was 6.84 and the standard deviation was 0.73 . The finding was in agreement with Muhammed- Lawal et al. (2009) and Akpomuvia (2010) assertions that a range of $4-6$ members constitute the modal household size among the rural farmers in Nigeria. In addition, the mean years of formal education among the respondents was $6.84 \pm 0.73$. This implies that farmers in Osun State are literates. This was in consonance with Farinde et al. (2007) report that the literacy level of farmers in Osun State was $49.0 \%$. The mean annual income of the farmers was N182,471 1 237.17. The mean years of agricultural production experience was $17.51 \pm 9.91$ years. This implies that farmers in the study area had high farming experience. This finding agreed with Farinde et al. (2007) assertion that farmers in Egbedore Local Government Area of Osun State had their mean years of experience as $16.91 \pm 10.38$. With high years of farming experience, farmers will be able to contribute to the scope of the study.

Table 1: Distribution of respondents by socio-economic characteristics

\begin{tabular}{|c|c|c|c|c|}
\hline Varaibles & Frequency & Percentage & Mean & St.Dev \\
\hline \multicolumn{5}{|l|}{ Age } \\
\hline$<30$ years & 17 & 5.8 & & \\
\hline $31-60$ years & 257 & 87.1 & 49.67 & 9.70 \\
\hline 61 years and above & 21 & 7.1 & & \\
\hline \multicolumn{5}{|l|}{ Sex } \\
\hline Male & 207 & 70.2 & & \\
\hline Female & 88 & 29.8 & & \\
\hline \multicolumn{5}{|l|}{ Religion } \\
\hline Christianity & 179 & 60.7 & & \\
\hline Islam & 116 & 39.3 & & \\
\hline \multicolumn{5}{|l|}{ Primary occupation } \\
\hline Farming & 174 & 59.0 & & \\
\hline Trading & 77 & 26.1 & & \\
\hline Artisan & 42 & 14.2 & & \\
\hline Civil service & 2 & 0.7 & & \\
\hline \multicolumn{5}{|l|}{ Farm size (acres) } \\
\hline $1-2$ & 91 & 30.8 & & \\
\hline $3-4$ & 157 & 53.3 & 2.74 & 0.38 \\
\hline $5+$ & 47 & 15.9 & & \\
\hline Years of formal education & & & 6.84 & 0.73 \\
\hline $\begin{array}{l}\text { Household size } \\
\text { Income/annum } \\
\text { Farming experience }\end{array}$ & & & 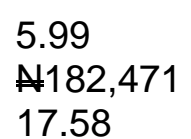 & $\begin{array}{l}2.11 \\
\text { A237.17 } \\
9.91\end{array}$ \\
\hline
\end{tabular}

Source: Field survey, 2012 


\section{Causes of youth migration}

Results in Figure 1 showed that absence of social amenities (89.8\%), poverty (80.3\%), search for better education (70.8\%), search of better wages $(65.4 \%)$ and unemployment $(56.3 \%)$ were the major causes of youth migration in Osun State. Other causes of migration identified were famine $(38.9 \%)$, employement and business opportunities $(36.9 \%)$ and better technology (23.1\%). The findings revealed that lack of social amenities such as electricity, good roads, pipe borne water, schools, hospital and so on were the major pull and push factors that discourage youths in Osun State to stay in the rural areas. The findings support Zainab and Mustapha, (2011) assertions that absence of social amenties and poverty were the major causes of youth migration from rural to urban cities in Borno State.

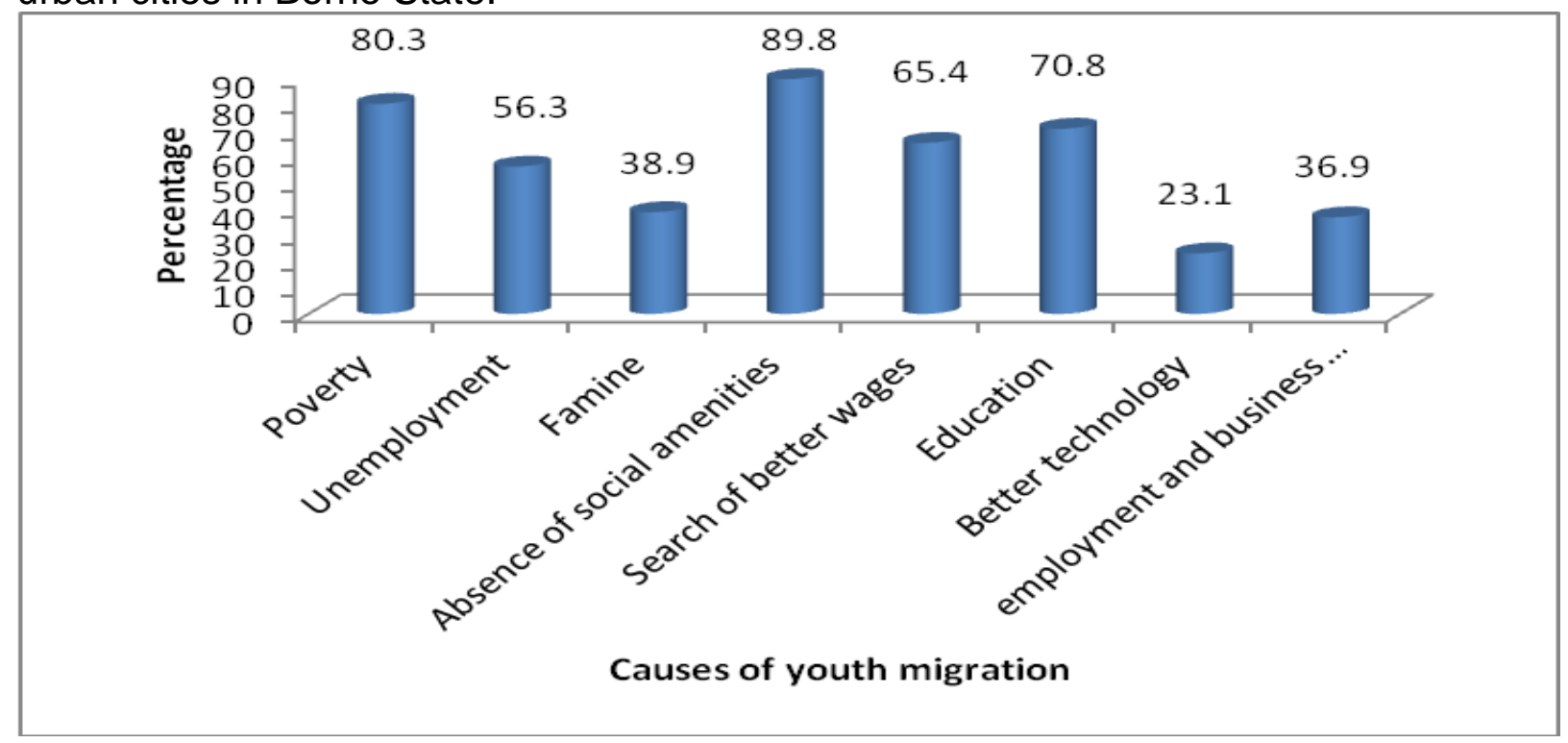

Figure 1: Causes of youth migration from rural areas of Osun State Multiple responses

Field survey, 2012.

\section{Effects of youth migration}

Results in Figure 2 showed that reduction in farm size (81.1\%), reduction in hired labour $(75.3 \%)$, reduction in household income $(73.9 \%)$, reduction in family labour $(68.1 \%)$ and low improvement in social amenities $(61.3 \%)$ were the major effects of youth migration on agricultural production in the study area. Also others effects identified were fall in the standard of living of the people (43.3\%) and low community development activities $(50.9 \%)$. This study implies that youth migration from rural to urban centre causes reduction in the size of farmland under cultivation, thereby reducing the the household income. It also reduced the number of family and hired labours. These are all negative consequences on the farming communities in Osun State. This findings conform with Akande et al. (2006), Nnadi et al. (2012), Batigna (2004), Madieu (2010) and Peter (2011) reports that reduction in farm size, hired and family labour and low improvement in social and community activities were the identified effects of youth migration in Nigeria, Kpandai, Siera Lone and Senegal. 


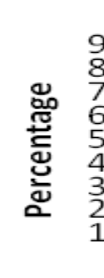

\section{1}
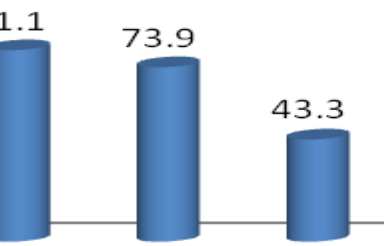

$68.1 \quad 75.3$
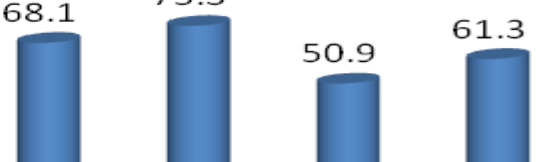

$80-$
$70-1$
$50-1$

0

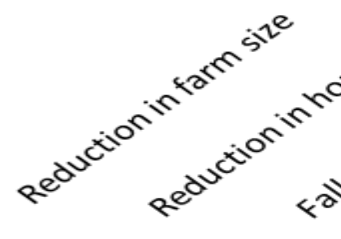

90.<smiles>[GeH2]CC[GeH3]</smiles>

20
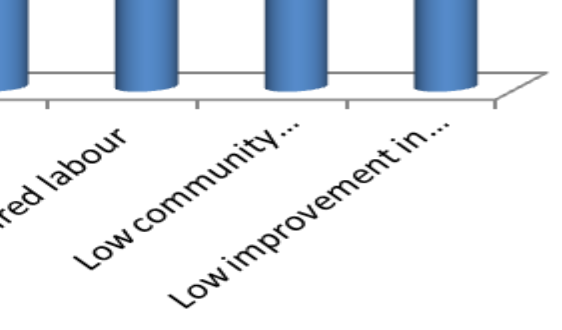

Effects of youth migration

Figure 2: Effects of youth migration

Source: Field survey, 2012.

Multiple responses.

\section{Relationship between effects of youth migration and level of agricultural}

\section{production}

Results of correlation analysis showed that there was a significant relationship between effect of youth migration that was computed from the total score of the effects of youth migration meausred with a 5 point likert scale and level of agricultural production $(r=-$ $0.634 ; p \leq 0.01)$ in Osun State. The coefficient of determination $\left(r^{2}=0.402\right)$ showed that effect of youth migration contributed about 40.2 per cent to the change in the level of agricultural production among farmers farmers. This implies that youth migration caused about 40.2 per cent in reduction of agricultural production in Osun State. The negative but significant relationship indicated that as more youths migrate to urban centres, there is reduction agricultural produce among the farmers in the host communities where these youth migrated. This finding corroborates the results showed in Figure 2 that reduction in farm size, family and hired labours were the identified effects of youth migration in the study area. This implies that there would be reduction in farmers' farm size as labour would become very scarce in the study area and it support Aboagye and Gunjal, (2000) and Akande et al. (2006) assertions that rural urban migration has significant effects on the level of agricultural production in Sub-Sahara Africa.

Table 2: Correlation between youth migration and level of agricultural production Variable

Correlation coefficient ( $r$ ) Coefficient of determination

$\left(r^{2}\right)$

Agricultural production $-0.634^{\star *}$ 0.402

Source: Field survey, 2012 


\section{Conclusion and Recommendations}

The effects of youth migration on rural farming communities had been a contending issue in literature and based on the economic theory of migration, people migrate because it is for their benefit. However, the study revealed that youth migration has some negative consequences on the rural areas where the migrants left. Migration of these active and agile people may resulted in leaving farming activities in the hands of the women and aged people, thereby causing a dratic reduction in the level of food production in the state. The study concludes that absence of social amenities in the farming communities, poverty and search for better education were the major causes of youth migration and reduction in farm size, family and high rate of hired labour were the common consequence of youth migration. The study recommends that infrastructural development should be hastened in farming communities if the government intends to retain the youth and promote food production in rural areas of Nigeria.

\section{References}

Akande, J. A, Adesiji, G, Akinpelu, O. I (2006). Effects of youth migration on farmers agricultural production in Egbedore Local Government Area of Osun State, Nigeria. Proceeding of the 8th National Research Conference and Network Meetings of CYIAP, Unilorin. Pp. 33-37.

Batigna Kubon (2004). The Effect of Rural Out-Migration on Agriculture in Salaga (East Gonja) District- A Case of Kpandai., http://www.imi.ox.ac.uk/onlinelibrary/1373\#sthash.9PmDIXqk.dpuf. International Migration Institute, London

Bnell T, E (2007). 'The influence of stocks and flows on migrants' locational choices',

Rev. Develop. Econ., 10(4): 65265.

CYIAP-Network (2006): Challenges faced by children and youth: The responses of

Development service providers in Nigeria. Torimiro, D.O and Adisa, B.O. (eds). Proceedings of the $8^{\text {th }}$ National Research Conference and Network Meeting of Children and Youth in Agriculture Programme in Nigeria (CYIAP-Network) held the Department of Agricultural Extension and Rural Development, University of Ilorin, Ilorin, Kwara State. November 27-30, 2006.

Farinde, A. J, Owolarafe, O. K, and Ogungbemi, O. I (2007). An overview of Production, Processing, Marketing and Utilisation of Okra in Egbedore Local Government Area of Osun State, Nigeria. Agricultural Engineering International: The CIGR Ejournal.Pp. 1-17.

Harris, T. B and Todaro, P. M (1970). "Urbanization, Unemployment, and Migration in Africa:

Theory andPolicy. Paper Prepared for Reviewing Social and Economic Progress in Africa. Dharam 
IFAD International Fund for Agricultural Development (2007). Sending money home, Rome,

Italy http://www.ifad.org/events/remittances/maps/brochure

Madieu, J (2010). Massive rural-urban migration and its impact on agriculture in Sierra Leone. Sierra Express Media

Muhammad-Lawal, A.; Omotesho, O. A. and Falola, A. (2009): Technical efficiency of youth participation in agriculture: A case study of the Youth - In - Agriculture Programme in Ondo State, South Western Nigeria Nigerian Journal of Agriculture, Food and Environment 5(1):20-26

Nnadi, F.N., Chikaire, J. Atoma, C.N., Egwuonwu, H.A., Echetama, J.A. (2012). Rural Youth Empowerment: A Panacea to Rural Urban Drift. A Case Study of EthiopeEast Area of Delta State. Science Journal of Sociology \& Anthropology. Pp. 9-15.

Olagunju, F.I., (2008). Economics of palm oil processing in South-Eastern Nigeria. International Journal of Agricultural Economics and Rural Development, 1(2): 6977.

Peter D. G (2011). Rural-Urban Migration and Agricultural Productivity: The Case of Senegal. PhD thesis submitted to the Department of Agricultural and Consumer Economics, University of Illinois,

Torimiro, D. O (1999). Understanding children in Agriculture programme in Nigeria. CYIAP

Bulletin No. 1.

Torimiro, D.O, Kolawole, D.O and Okorie, V.O (2007). In-school farm youth and ICT usage: A gender analysis of Nigeria's Yoruba communities. Journal of youth studie, Vol 2, isuue no. 1.

UNDP. United Nations Development Programme (2005). "The Millennium Development Goals Report 2005”: Consulted online in December 2007.

Zainab, G and Mustapha, G. K (2011). Causes and Effects of Rural-Urban Migration in Borno State: A Case Study of Maiduguri Metropolis. Asian Journal of Business and Management Sciences. Vol. 1 No. 1 [168-172] 